\title{
Processos participativos para elaboração de Planos Diretores Municipais: inovações em experiências recentes
}

\author{
Participatory processes for preparation of Urban Plans and Zoning: \\ recent experiences innovations
}

Eleusina Lavor Holanda de Freitas ${ }^{[0]}$, Laura Machado de Melo Bueno ${ }^{[b]}$

\author{
[a] Demacamp, Campinas, SP, Brasil \\ [b] Pontifícia Universidade Católica de Campinas (PUC-Campinas), Campinas, SP, Brasil
}

\section{Resumo}

A Constituição Brasileira de 1988 instituiu a democracia participativa. Em 2001, o Estatuto da Cidade tornou lei federal a cidade justa e sustentável e vinculou a participação à implementação dessa nova política urbana, de responsabilidade municipal. Em 2016, uma segunda leva de planos diretores foi elaborada, passando de "experiências" para tornar-se processo com peso nas decisões políticas. Arquitetos urbanistas estão entre os mais envolvidos. Atores sociais ligados à questão urbana se perguntam como melhorar e dar qualidade à participação no processo de revisão da legislação urbanística. Este texto apresenta métodos de trabalho nos processos participativos implementados que possam inspirar profissionais envolvidos com a democratização das cidades. São discutidos os casos dos municípios de Jundiaí e de Vinhedo, no Estado de São Paulo, que, com a introdução de inovadora metodologia participativa e com base em diferentes instrumentos de pesquisa, conseguiram resultados em leis que refletem um projeto de cidades mais democráticas e inclusivas.

Palavras-chave: Planejamento urbano no Brasil. Política urbana. Lei Federal Estatuto da Cidade. Processo participativo. Legislação urbanística.

\section{Abstract}

The Brazilian Constitution of 1988 established participatory democracy. In 2001, the City Statute makes federal law fair and sustainable to the city and binds the participation to the implementation of this new urban policy a municipal liability. In 2016, a second wave of plans was developed, transitioning from "experiences" to a strong process in policy decisions. Architects and planners are among the most involved. Social actors connected to the urban matters ask themselves how to improve and give quality to the participation in the process of revision of urban codes. This text presents a method in participatory processes implemented, which can inspire professionals involved with the democratization of the cities. We discuss cases of Jundiai and Vinhedo, municipalities in the State of São Paulo. The introduction of innovative participatory methodology, including different surveys, resulted in laws that reflect a project for a more democratic and inclusive city.

Keywords: Urban planning in Brazil. Urban policy. Federal Law Statute of the City. Participatory process. Urban legislation.

ELHF é doutora em Arquitetura e Urbanismo (FAU-USP), e-mail: eleusina@demacamp.com.br LMMB é doutora em Arquitetura e Urbanismo (FAU-USP), professora da FAU e do PósUrb da PUC-Campinas, e-mail: laurab@puc-campinas.edu.br 


\section{Introdução}

Desde a aprovação da Lei Federal no 10.257/2001, denominada Estatuto da Cidade, o Plano Diretor (PD) passou a ser o instrumento legal básico da política de desenvolvimento e expansão urbanos (Brasil, 2001). Deveria então determinar como a cidade e a propriedade cumpririam sua função social. Tornou-se obrigatória a elaboração e a revisão de planos diretores para todos os municípios brasileiros com população acima de 20 mil habitantes, inseridos em regiões metropolitanas, situados em áreas de interesse turístico e próximos de empreendimentos de significativo impacto ambiental (art. 41 da Lei no 10.257/2001). Em 2009 (IBGE), havia 5.570 municípios no Brasil, dos quais 1.644 com mais de 20 mil habitantes. Destes, 87\% (1.433) declararam ter PD na época.

A herança histórica de desigualdades socioespaciais decorrentes do injusto processo de urbanização no Brasil resiste ainda aos chamados instrumentos para democratização da cidade. 0 crescimento econômico com base em baixos salários construiu cidades excludentes e desiguais, com crescimento maior da população urbana do que a rural desde os anos de 1930 (Oliveira, 1982). A desigualdade social no Brasil é fruto da herança patrimonialista, de um processo de dominação do Estado e de seus investimentos pelos interesses das elites. A captura da esfera pública pelo capital privado comprometeu o desenvolvimento urbano sustentável no Brasil (Faoro, 1977).

0 processo de urbanização orientado pelos interesses privados, sobretudo os envolvidos com os negócios do desenvolvimento urbano, construiu espaços urbanos pouco sustentáveis. As boas localizações têm altos preços. A população trabalhadora conseguiu se fixar apenas nas periferias: favelas, cortiços e loteamentos clandestinos. 0 período de redemocratização foi acompanhado de fortes processos de revalorização dos espaços intraurbanos. Mais recentemente, os ganhos imobiliários se expandiram, envolvendo implantação de grandes obras públicas e novos negócios. A população de menor renda foi sendo expulsa para regiões precárias e desprovidas de infraestrutura urbana.

No art. 40, o Estatuto da Cidade define como obrigatória a promoção de debates com a participação da população e de associações representativas dos vários segmentos da comunidade, no processo de elaboração dos PDs. Entretanto, não considera a complexidade das disputas travadas no âmbito local, deixando para o município a mediação dos conflitos entre o direito privado e o interesse público. 0 Estatuto da Cidade impõe clara separação entre o direito de propriedade e o direito de construir. Esperava-se que o processo participativo pudesse ser um instrumento capaz de definir pactos e inverter prioridades (Ferreira, 2009).

Nesse contexto, insere-se a campanha nacional "Plano Diretor Participativo: Cidade de Todos", promovida pelo Governo Federal, Ministério das Cidades, em 2005, com o apoio do CONFEA ${ }^{1}$, para a elaboração dos planos diretores participativos (PDP). A elaboração ou a revisão dos planos teria então a missão de lidar com conflitos urbanos históricos de cidades, marcados pela privatização do interesse público, enfatizando-se a democratização do processo de decisão sobre a cidade (Brasil, 2004).

Após o término da campanha nacional dos PDPs, muitos foram os estudos e as análises realizados para avaliar os resultados dos novos planos. Estudos mostram processos participativos incipientes, frágeis, com participação pouco representativa (Santos \& Montandon, 2011; Burnett, 2011; Rolnik, 2008; Villaça, 2006; Bueno \& Cymbalista, 2007). Muitos planos continuaram a ser meros documentos "de gaveta", pouco usados e desconhecidos, o que Villaça (2006) define como "plano discurso". No entanto, outros instrumentos, como Operações Urbanas e Solo Criado e leis de uso e ocupação do solo (LUOS), zoneamento, parcelamento do solo, código de obras, legislação ambiental, continuaram ditando a produção do espaço urbano em detrimento do PDs, de pouca autoaplicabilidade, sendo feitos por técnicos municipais ou contratados, sem a participação da sociedade (Burnett, 2011; Santos \& Montandon, 2011; Cymbalista \& Santoro 2009; Villaça, 2006; Maricato, 2011; Rolnik, 2008).

Por que os resultados têm sido tão insatisfatórios? Quais são as causas da baixa aplicação dos conteúdos dos planos aprovados? Neste artigo, procura-se analisar a capacidade de métodos participativos inovadores para elaboração de planos autoaplicáveis a partir de dois casos.

Os governos não têm sido cobrados pela implementação dos planos porque os processos de discussão fracassaram em envolver a população, não foram reconhecidos pelos atores locais, foram pouco divulgados ou mesmo não

\footnotetext{
${ }^{1}$ Conselho Federal de Agronomia e Engenharia, que, na época, englobava os arquitetos urbanistas, período anterior à criação do Conselho de Arquitetura e Urbanismo (CAU), em 2010.
} 
se aprofundaram em temas necessários para que um novo pacto territorial fosse efetivado.

Algumas hipóteses podem ser levantadas. 0 desinteresse da população pelo PD pode ser uma explicação, em muitos casos pela própria natureza do documento proposto, ou seja, PDs que não incluíram o aprofundamento sobre parâmetros de uso e ocupação do solo, tornando-se leis pouco úteis. A falta de poder de deliberação também pode ser uma das razões do desinteresse. Processos participativos de caráter consultivo são frágeis por serem pouco envolventes, sem construção de compromissos entre os atores. Processos participativos que envolvem apenas representantes de entidades de setores interessados ${ }^{2}$ no desenvolvimento urbano acabam por determinar uma visão de futuro no PD apenas voltada para o interesse econômico e a valorização dos preços dos imóveis, distanciando a população do processo e, geralmente, desencadeando impactos negativos sobre o direito à cidade saudável e sustentável. Processos participativos restritos a audiências públicas dão pouca condição para que o cidadão participe com conhecimento para poder opinar.

Observam-se pouco interesse e investimento dos órgãos públicos, empresas de consultoria e pesquisadores no conhecimento e desenvolvimento de metodologias de trabalho que considerem o aprimoramento da participação como elemento central para a efetividade de pactos legítimos sobre o território.

Neste artigo, são apresentados métodos recentes utilizados em municípios que contrataram consultoria para a elaboração de PDs, comprometidos com processos participativos efetivos que, para garantir sua aplicação, incluíram o detalhamento das normas de uso, ocupação e parcelamento do solo. Foram desenvolvidas inovações nos métodos e instrumentos de consulta - pesquisas com amostras estatisticamente representativas da população de diferentes bairros, questionários a entidades e canais na Internet - que possibilitaram desenvolvimento de argumentos, propostas e contrapostas às dos setores tradicionalmente hegemônicos na elaboração da legislação municipal.

\footnotetext{
${ }^{2} 0$ termo "stakeholder", bastante utilizado na literatura referente a planejamento estratégico, representa esse desvio na seleção dos envolvidos, privilegiando os setores que têm interesse econômico nas decisões que serão tomadas. Já o termo "sociedade civil organizada" abrange grupos sociais com demandas, mas com menor capacidade política de serem ouvidos.
}

Os estudos de casos trazidos aqui são dos municípios de Vinhedo (2005-2007) e de Jundiaí (2014-2016), no Estado de São Paulo. O PD de Vinhedo (2006) faz parte da primeira leva de PDs pós-Estatuto da Cidade. Por isso, foi objeto de vários estudos e pesquisas (Santoro, 2012; Rolnik, 2008; Freitas, 2008). Já o PD de Jundiaí (2016a), aprovado em 2016, reflete um amadurecimento, concretizando a autoaplicabilidade. Incorpora detalhamentos para aplicação dos instrumentos, incluindo a regularização fundiária de interesses social e específico.

Vinhedo possuía em 2004, segundo a Fundação SEADE (2004), 53.661 habitantes, o que representava $2 \%$ da população da Região Metropolitana de Campinas. Em 2000 (IBGE), 40\% dos domicílios particulares permanentes tinham rendimento mensal domiciliar superior a 10 salários mínimos (SM), 30\%, entre 5 e 10 SM, $15 \%$, entre 5 e 3 SM, e 15\%, até 3 SM. Foi governada entre 2005 e 2008 por Kalu Donato (prefeito), filiado, à época, ao Partido da República (PR), e Marcos Ferraz (vice-prefeito), filiado, à época, ao PFL.

A Demacamp foi contratada por meio da modalidade de carta-convite para a elaboração do PD do município de Vinhedo (2006), contrato gerido pela Secretaria de Obras. As atividades foram realizadas entre novembro de 2005 e novembro de 2006 . 0 projeto de lei foi enviado à Câmara Municipal em novembro de 2006 e aprovado em janeiro de $2007^{3}$, com pequenas alterações. A lei aprovada incluiu os conteúdos do PD e aqueles da LUOS, como o zoneamento e os parâmetros urbanísticos de uso e ocupação do solo, tendo suas deliberações e principais polêmicas explicitadas no processo participativo. Em consonância com o Ministério Público, o PD instituiu um instrumento de regularização com compensação para loteamentos que haviam sido fechados com áreas municipais públicas em seu perímetro, por meio de cessão de novas áreas públicas, obras ou pagamento em pecúnia, para o Fundo Municipal de Desenvolvimento Urbano, que também recebe recursos da Outorga Onerosa. Apesar de conhecida pela qualidade ambiental, Vinhedo possui vigoroso parque industrial, com passivos. Por processo semelhante ao dos loteamentos fechados e com base no diagnóstico do PD, as indústrias foram obrigadas pelo Ministério Público a fazer compensação ambiental com obras públicas, dessa forma construindo a Represa

\footnotetext{
${ }^{3}$ Lei Complementar no 66, de 17 de janeiro de 2007. Dispõe sobre Plano Diretor Participativo de Vinhedo (PDPV) e dá outras providências (Vinhedo, 2007).
} 
IV, do sistema de abastecimento municipal de água. O município delimitou no PD zonas especiais de interesse social (ZEIS) para habitação popular, além de zonas especiais de interesse agrícola (ZEIAG) para proteger a produção agrícola dentro da área urbana, com redução do perímetro urbano. 0 zoneamento considerou a oferta de infraestrutura urbana, em especial a água, com proposição de aumento da densidade em bairros consolidados. A demarcação das ZEIS e das áreas de preempção foi realizada com base em um extenso levantamento de vazios urbanos, utilizando as informações do cadastro imobiliário e a fotointerpretação.

Jundiaí possuía em 2010, segundo o IBGE (2010), 370.126 habitantes, o que representava 53\% da população total do Aglomerado Urbano de Jundiaí. Em 2010 (IBGE), 22,3\% dos domicílios particulares permanentes tinham rendimento mensal domiciliar superior a 10 SM, 28\%, entre 5 e 10 SM, $43,5 \%$, entre 5 e 1 SM, e 6,2\%, até 1 SM. 0 então prefeito (2013-2016), Pedro Bigardi, era filiado ao PC do B e, em janeiro de 2016, transferiu-se para o PSD. 0 vice-prefeito, Durval Orlato, era filiado ao PT. A Demacamp foi contratada por meio da modalidade de licitação por proposta técnica e preço, tendo como objeto: capacitação e pesquisa; revisão, adequação e elaboração da legislação urbanística municipal. O contrato foi acompanhado pela Secretaria Municipal de Planejamento e Meio Ambiente (SMPMA). As atividades foram realizadas de novembro de 2013 a março de 2016. 0 projeto de lei foi enviado à Câmara Municipal em março e aprovado em junho de $2016^{4}$, com poucas emendas, que não descaracterizaram a proposta. A lei aprovada também incluiu os conteúdos do PD e da LUOS, com o zoneamento e os parâmetros urbanísticos. Houve redução do perímetro urbano e foi criado o Fundo Municipal de Desenvolvimento Territorial, gerido pelo Conselho Municipal de Política Territorial, de caráter deliberativo, que priorizou a destinação de seus investimentos para a política de habitação social (25\%) e para o desenvolvimento rural (20\%). A regularização de loteamentos de média e alta renda também ficou condicionada à compensação financeira, com a criação de um fator variável de acordo com a localização. Foram instituídos limites para verticalização, restrita a vias previamente

\footnotetext{
${ }^{4}$ Lei no 8.683, de 7 de julho de 2016. Institui o Plano Diretor do município de Jundiaí e dá outras providências (Jundiaí, 2016a).
}

determinadas no zoneamento, seguindo critérios de controle da densidade em áreas distantes do centro. Foi realizada a delimitação de ZEIS de vazios com base no Plano de Habitação. 0 controle do miolo dos bairros foi incluído, limitando o uso não residencial e a verticalização em vias locais de acesso ao lote.

No artigo, procura-se enfatizar como uma metodologia ${ }^{5}$, incorporando pesquisas e processos participativos deliberativos e explicitando diferenças e conflitos, possibilita negociações transparentes e encaminhamento de decisões.

Qual seria a validade de estudar apenas dois casos, no contexto de mais de 2 mil PDs já realizados em todo o Brasil? Alves-Mazzotti (2006) examina aspectos fundamentais sobre o uso de estudos de caso quanto à validade de generalização de conclusões, conforme sua representatividade em relação ao fenômeno estudado, bem como quanto à validade de questionar conclusões de outras pesquisas com base em especificidades de estudo de casos.

A singularidade dos casos apresenta-se como principal argumento favorável. Em diversos casos citados na literatura por processos participativos robustos, como foi o de Santo André, que se tornou referência no Brasil, e para o desenvolvimento da metodologia apresentada neste artigo, a equipe técnica era da própria Prefeitura Municipal. Entretanto, foram muitos os municípios, inclusive apoiando-se nos recursos federais, que contrataram consultorias técnicas, sendo esse o caso tratado aqui, que envolve outros desafios, desde o poder de decisão técnica e política até o dimensionamento das horas técnicas necessárias para um processo participativo. Outro aspecto que reforça o interesse científico é que há uma forte crítica quanto à frustração resultante da elaboração dos PDs decorrente de sua baixa autoaplicabilidade. A literatura coloca que a postergação da aprovação da legislação de uso, ocupação e parcelamento do solo e mesmo da aplicação dos instrumentos urbanísticos tem inviabilizado a concretização dos objetivos e das metas dos PDs. Os casos aqui tratados diferenciam-se, pois o objeto contratual explicitamente define a necessidade da elaboração do Plano e a legislação de uso e ocupação

\footnotetext{
${ }^{5}$ A metodologia descrita neste artigo foi desenvolvida por uma equipe de profissionais que trouxeram suas experiências para a Demacamp, destacando-se a coordenação técnica do Arq. Sidney Piochi Bernardini e a coordenação do processo participativo da Arq. Paola Paes Manso, ambos da equipe de coordenação do PD de Santo André.
} 
do solo por processo participativo, aprovado em um mesmo momento como lei complementar.

\section{A interrelação entre conteúdo e processo}

O conteúdo mínimo do PD está definido no art. 42 do Estatuto da Cidade e detalhado pelo Conselho Nacional das Cidades na Resolução no 34 de 2005. Entretanto, encontram-se muitas diferenças quanto ao escopo de abrangência nas peças técnicas produzidas em diferentes municípios.

Após a conclusão das primeiras experiências de elaboração e revisão de PDs pós-Estatuto da Cidade, pesquisas constataram que, embora elaborados sob a exigência da autoaplicabilidade trazida pela lei federal, grande parte dos planos optou por excluir do conteúdo as definições relativas ao uso e ocupação do solo, remetidas para nova LUOS, a ser revistas a partir do PD (Santos \& Montandon, 2011; Rolnik, 2008; Bueno \& Cymbalista, 2007, entre outras).

Essa decisão tem comprometido, de certa forma, a autoaplicabilidade dos PDs, retirando do seu âmbito a discussão mais abrangente sobre os conflitos inerentes à concessão de índices e de parâmetros urbanísticos constantes do zoneamento e das expectativas de valorização imobiliária. Uma lei posterior de zoneamento encaminha essas discussões decisivas para os velhos fóruns ${ }^{6}$ com empreendedores imobiliários. As municipalidades optam por deixar a definição dos conteúdos do uso, da ocupação e do parcelamento do solo para a revisão da LUOS existente ou, ainda mais grave, continuam a gerir a produção do espaço com base na legislação anterior ao PD, sem incorporar os objetivos, as diretrizes e os instrumentos do Estatuto da Cidade.

O PD torna-se repetidamente uma carta de intenções, sem importância para a cidade. Esvaziam-se os conteúdos e, consequentemente, a possibilidade de os conflitos serem discutidos publicamente. A simples obrigatoriedade da participação nos processos de discussão de PDs, conteúdos de difícil compreensão e abstratos, não mobilizam a população. Boa parte dos moradores tem pouco conhecimento sobre as consequências da inclusão ou exclusão de

\footnotetext{
${ }^{6}$ Muitos municípios têm comissões permanentes para revisão de legislação: Conselhos de Desenvolvimento Urbano, Conselho do Plano Diretor, ou mesmo comissões constituídas por meio de decreto do Executivo.
}

princípios, diretrizes, instrumentos urbanísticos e fiscais na legislação, bem como sobre a estrutura da gestão pública, o papel do Executivo e Legislativo e a organização do orçamento municipal. A desigual condição de compreensão dos conteúdos reduz a possibilidade de diálogo.

Assim, a metodologia preconizada neste artigo para elaboração do PD é a inclusão dos conteúdos do uso, da ocupação e do parcelamento do solo, em um processo de capacitação e atividades de formação, que envolve não só a temática das políticas territoriais municipais, mas também a gestão pública, o papel do Executivo e Legislativo e a organização do orçamento municipal nos processos de elaboração de PDs. Dessa forma, embora o escopo apresentado se limite à elaboração do PD, a metodologia incorpora atividades de capacitação como meio de garantir a aplicação da lei pelos gestores públicos e o controle social pela sociedade. A formação organiza o processo.

A noção de que bastam conselhos, fóruns e audiências públicas para que a participação ocorra tem se mostrado falsa, uma idealização refletida muitas vezes nas exigências legais.

Há uma distância imensa entre discurso e pratica entre nós. Invariavelmente textos dos planos diretores são sempre muito bem intencionados, afirmam uma cidade para todos, harmônica, sustentável e democrática. A implementação do plano, entretanto tende a seguir a tradição: o que favorece a alguns é realizado, o que os contraria é ignorado (Maricato, 2011).

Os processos observados nesta pesquisa mostram que o método de promover a participação é fator definidor do sucesso na elaboração e aprovação do PD.

A participação precisa ser estruturada a partir da construção de uma esfera pública de discussão sobre a cidade, que não está pronta e, portanto, constitui-se durante o processo. A primeira pergunta que se faz é: como atrair moradores para essa discussão? 0 desafio é aglutinar indivíduos representativos e interessados, formando um grupo que represente os diferentes segmentos e interesses sobre a cidade.

A transparência e a publicidade do processo, os resultados, o cronograma, a forma de funcionamento dos fóruns de discussão são fundamentais. A participação deve se iniciar desde o diagnóstico para que possa evoluir na construção de uma proposta, proporcionando conhecimento, discussão e condições para sua 
negociação, sistematizada pelo governo e submetida à população e ao Legislativo.

Situar o cidadão - em sua diversidade social, econômica, cultural e territorial - no processo de discussão é sempre a primeira tarefa, pois permite agregar atores no processo e orientar aqueles que chegam sobre o ponto em que estamos.

A Figura 1 apresenta o processo em sua forma geral, os fóruns que vão sendo criados e os momentos em que os resultados são apresentados e discutidos.

Na preparação do processo, é constituído um primeiro grupo, denominado gestor, com o objetivo de acompanhar e legitimar a construção do processo. Esse grupo é indicado pelo governo e possui representantes dos mais diversos segmentos sociais.

Após a apresentação do diagnóstico (1ํ Fórum), já se podem eleger representantes (delegados), escolhidos por seus grupos ou setores, que terão direito a voto. A equipe municipal e a consultoria sistematizam percepções e sugestões, elaborando uma proposta de conteúdo para o PD. São feitas diversas reuniões com os conselheiros e também com seus grupos e setores. No caso de Jundiaí, foram feitas também oficinas territoriais em razão das especificidades socioespaciais e do tamanho do município. Um canal de comunicação é também aberto com toda a população pela Internet. Dentro do Executivo também ocorrem discussões, com construção de propostas por meio de reuniões intersecretariais. Os resultados da Internet e das reuniões são sistematizados na proposta, destacando os conflitos. Abrem-se então mesas de negociação (após o 2 o Fórum), que geralmente resultam em propostas consensuadas. A proposta do conteúdo do PD é levada ao Congresso da Cidade, no qual os delegados eleitos votam as propostas conflitantes. 0 resultado é enviado pelo prefeito à Câmara Municipal.

Durante todo o processo, um grupo técnico é constituído, reunindo profissionais das diversas secretarias, especialmente aquelas ligadas às questões territoriais: meio ambiente, planejamento urbano, transporte e mobilidade, saneamento, agricultura, obras, entre outras.

\section{Transparência nas regras do jogo: participar em iguais condições}

Muito se comenta sobre a falta de interesse da população em participar de processos de discussão sobre o futuro da cidade. Deve-se ponderar, porém, até que ponto o desinteresse decorre da falta de clareza quanto ao processo. Consequentemente, quem participa não sabe de antemão qual é seu poder de interferir na proposta final.

0 caráter deliberativo do processo é o principal motivo de engajamento dos participantes, em especial dos setores não diretamente vinculados a negócios imobiliários. A possibilidade de introduzir conteúdos e sugerir modificações fortalece e empodera cada delegado tanto em relação ao grupo/setor que representa

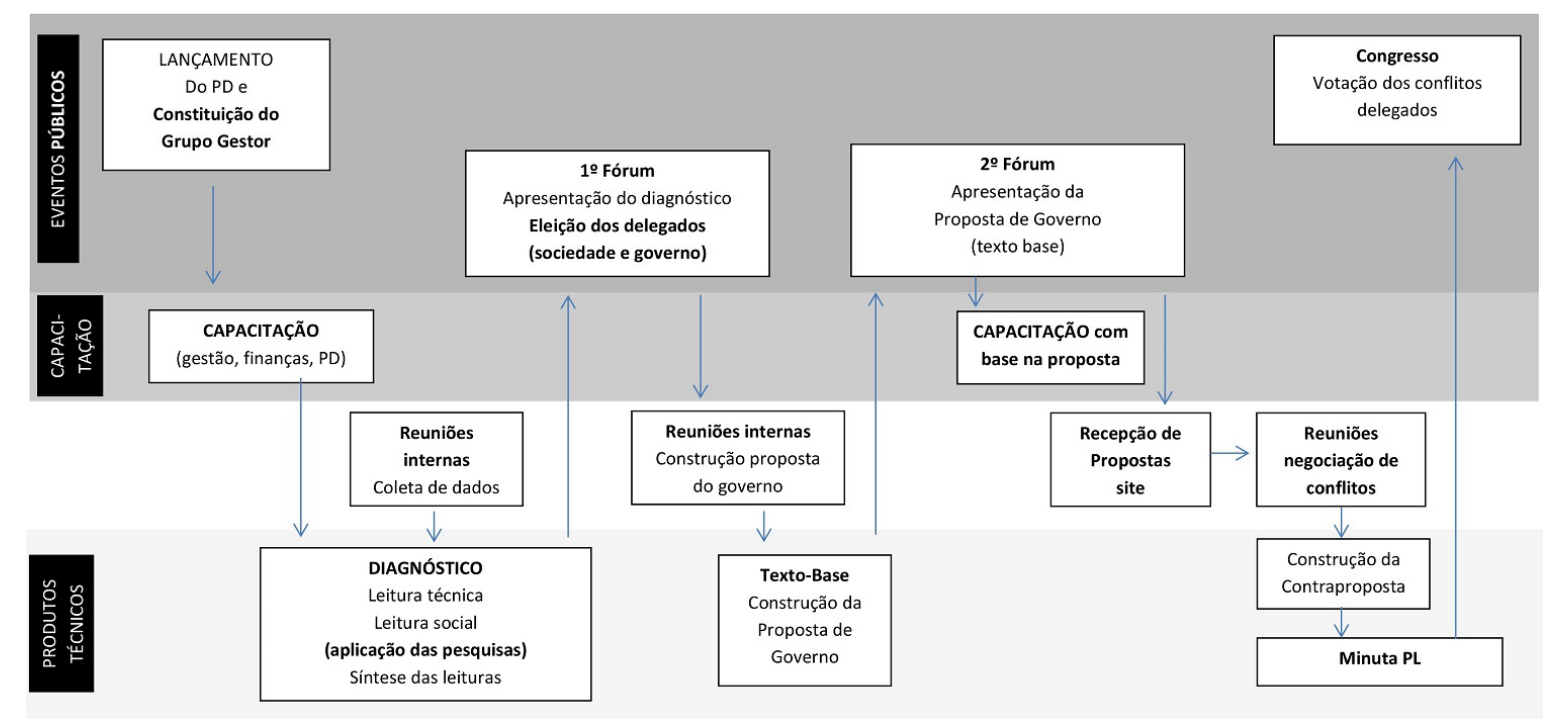

Figura 1 - Organograma do Plano Diretor

Fonte: Elaboração própria, com base em organograma elaborado pela arquiteta Paola Paes Manso (Consórcio Demacamp/Polis/Oficina, 2013). 
como também em relação aos representantes dos demais segmentos. 0 processo deliberativo forma atores políticos.

A ação que desencadeia a elaboração do PD precisa estar vinculada à definição e à divulgação do processo. Na metodologia em tela, o primeiro passo é constituir um grupo gestor formado por membros do governo e da sociedade civil, indicado pela Prefeitura e instituído por decreto (Quadro 1). 0 grupo acompanhará o processo desde o início, até que se possam eleger delegados da sociedade civil e governo, que serão, assim, legitimados para decidir, votar e interferir nos conteúdos da proposta de governo.

As equipes da consultoria e da Prefeitura, por meio das pesquisas, dos levantamentos e dos estudos, alimentam o processo, destacando-se as atividades de formação e de mobilização de setores, tratadas adiante.

A eleição dos delegados para o Conselho Deliberativo (Quadro 2) deverá acontecer depois da apresentação do diagnóstico, antes do início da discussão das propostas. No caso de Vinhedo, os delegados foram eleitos oito meses após o início do processo; em Jundiaí, 11 meses depois.

Em Vinhedo, no 1ํㅜ Fórum, foi apresentado o diagnóstico, contemplando um cruzamento entre as leituras técnica, jurídica e comunitária. Envolveu a apresentação dos conteúdos levantados, mapas e esclarecimentos de dúvidas. Um documento com a compilação da leitura foi distribuído à população e encartado em jornal diário da cidade.

Quadro 1 - Conselho ou Grupo Gestor: composição e atribuiç̃os

\begin{tabular}{|c|c|c|}
\hline & Vinhedo & Jundiaí \\
\hline Composição do Conselho Gestor & $\begin{array}{l}17 \text { representantes do governo, de movimentos sociais, ONGs, } \\
\text { entidades técnicas, acadêmicas e de pesquisa, e empresários ligados à } \\
\text { produção da cidade. }\end{array}$ & 40 representantes, sendo 40\% do Poder Público e 60\% da sociedade civil. \\
\hline Atribuiç̦ões & \multicolumn{2}{|c|}{$\begin{array}{l}\text { - Coordenaç̃ão geral do Plano. } \\
\text { - Condução. } \\
\text { - Monitoramento. } \\
\text { - Discussão da metodologia participativa e da estratégia de mobilização social. } \\
\text { - Não deliberação sobre o conteúdo do Plano. } \\
\text { - Deliberaç̃ão sobre o processo de construção do Plano. }\end{array}$} \\
\hline
\end{tabular}

Fonte: Elaboracão própria.

Quadro 2 - Composição do Conselho Deliberativo (delegados)

\begin{tabular}{|c|c|c|}
\hline & Vinhedo & Jundiaí \\
\hline Total de delegados & 75 & 101 \\
\hline \multirow[t]{10}{*}{ Composição } & & \\
\hline & \multirow{2}{*}{$\begin{array}{l}\text { - } 40 \% \text { do governo } \\
\text { (30 representantes). }\end{array}$} & - 40 representantes do Poder Público. \\
\hline & & \\
\hline & \multirow{2}{*}{$\begin{array}{l}\text { - } 15 \% \text { de entidades técnicas e ONGs } \\
\text { (11 representantes). }\end{array}$} & - 61 representantes da sociedade civil: \\
\hline & & $\checkmark 31$ representantes de movimentos sociais, agrupados em 13 regiões. \\
\hline & \multirow{2}{*}{$\begin{array}{l}\text { - } 20 \% \text { de empresários } \\
\text { (15 representantes). }\end{array}$} & $\checkmark 8$ representantes de trabalhadores - sindicatos. \\
\hline & & $\checkmark 10$ representantes de empresários. \\
\hline & \multirow{2}{*}{$\begin{array}{l}\text { - } 25 \% \text { de movimentos sociais } \\
\text { (19 representantes). }\end{array}$} & $\checkmark 8$ representantes de entidades profissionais, acadêmicas e de pesquisa. \\
\hline & & $\checkmark 4$ representantes de ONGs e coletivos organizados. \\
\hline & Eleitos no $1^{0}$ Fórum. & Eleitos no $2^{0}$ Fórum. \\
\hline
\end{tabular}

Fonte: Elaboração própria. 
Em Jundiaí, o 2ํㅜㅇórum apresentou a proposta de ordenamento territorial envolvendo: proposta de zoneamento, parâmetros e instrumentos urbanísticos. Esses conteúdos foram objeto de uma capacitação com duração de uma semana que aprofundou os temas com os delegados eleitos.

A eleição dos delegados, por voto aberto, marca o início de uma nova fase de discussão do PD, quando estes terão o poder de decisão e o voto na conferência final do plano. O Conselho Gestor inicial se dissolve. Entretanto, muitos participantes se legitimam no processo. Grande parte dos membros do Conselho Gestor que haviam sido indicados pela Prefeitura, devido ao seu envolvimento e à sua representatividade, é eleita pelos seus segmentos como delegados para o Conselho Deliberativo.

A escolha dos representantes dos segmentos e do movimento social ocorre no $2^{2}$ Fórum. Dessa forma, apenas aqueles presentes podem disputar a vaga como delegado. Após a discussão e votação, os representantes são oficialmente apresentados no dia do evento.

\section{Durante todo o processo: formação, capacitação e transparência}

Os processos aqui analisados promoveram a participação direta de movimentos sociais e de grupos organizados na discussão sobre o que querem da cidade, disputando seu território de forma democrática, o que pressupõe condições mais isonômicas de participação. É necessário conhecer informações sobre a cidade e as ferramentas disponíveis, tanto no que se refere à elaboração e compreensão de um diagnóstico da situação existente quanto ao papel da estrutura de gestão municipal e da legislação urbanística, seu alcance possível e suas limitações.

Dessa forma, a atividade de capacitação se torna fundamental, pois é o meio pelo qual a sociedade organizada, os movimentos sociais e a equipe da Prefeitura nivelam e aprofundam seu conhecimento técnico, realizam questionamentos e passam a construir um vocabulário comum.

Nos casos analisados, as capacitações (Quadro 3) foram oferecidas aos representantes dos conselhos municipais e também aos delegados eleitos, incluindo temas, como a construção de instâncias democráticas na gestão urbana, o conhecimento sobre a organização política municipal (Executivo, Legislativo e Judiciário) e a montagem e fonte de recursos do Orçamento Municipal. As atividades foram estruturadas tendo como referência o próprio município.

A primeira capacitação se dá no início do processo. A aproximação da população dos conteúdos técnicos é feita com a apresentação de experiências de outros municípios, selecionados em comum com a equipe municipal e sociedade civil, e traz grande incentivo ao processo de adesão à participação.

Em Jundiaí, uma segunda capacitação foi realizada na etapa de discussão da proposta de governo.

0 processo de elaboração e revisão da legislação urbanística, além de atingir a população e os segmentos organizados, envolve atuar com os técnicos e gestores para atualização profissional e compreensão dos processos de disputa territorial. É fundamental a preparação dos gestores e da equipe para liderança da

Quadro 3 - Oficinas de capacitação (conteúdos envolvidos)

\begin{tabular}{|c|c|c|}
\hline & Temas da oficina de capacitação 1 & Temas da oficina de capacitação 2 \\
\hline Jundiaí & $\begin{array}{l}\text { - Democracia, participação, conselhos e fundos. } \\
\text { - Planejamento territorial e gestão urbana. } \\
\text { - Políiticas públicas sociais e orçamento municipal. } \\
\text { - Instrumentos urbanísticos. }\end{array}$ & $\begin{array}{l}\text { - Princípios e diretrizes da política urbana. } \\
\text { - Macrozoneamento e zoneamento. } \\
\text { - Instrumentos urbanísticos. } \\
\text { - Parâmetros de uso e ocupação. } \\
\text { - Sistema de gestão e fundos. }\end{array}$ \\
\hline Vinhedo & $\begin{array}{l}\text { - Sensibilização sobre construção social e política do processo de urbanização. } \\
\text { - Implicações ambientais do processo de urbanização. } \\
\text { - Óticas de planejamento. } \\
\text { - Origem do Estatuto da Cidade. } \\
\text { - Papel do PD e do Estatuto da Cidade. }\end{array}$ & - Instrumentos urbanísticos. \\
\hline
\end{tabular}

Fonte: Elaboração própria. 
condução do processo e monitoramento da aplicação da legislação aprovada.

O estabelecimento de um novo pacto territorial por meio do PD pressupõe muitos diálogos internos ao governo, entre secretarias, técnicos e prefeito, Legislativo e população, o que necessariamente exige capacidade de coordenação e de gestão. A construção do pacto extrapola a esfera de decisão técnica, envolvendo decisões políticas, nem sempre previstas ou acordadas entre prefeito e secretários no período de definição de coligações partidárias eleitorais e de formação do governo.

A prática política nas eleições municipais é a organização de chapas e a formação de governos de coalização, muitas vezes com disparidades com as coalizões nacionais. Assim, muitas vezes os gestores e técnicos defendem interesses contraditórios em relação aos princípios legais sobre a qualidade de vida e a cidadania no ambiente construído ${ }^{7}$ defendidos por delegados militantes da reforma urbana. Conforme Maricato (2006, p. 216),

[...] a experiência histórica com planos diretores no Brasil mostra que eles se aplicam apenas a uma parte da cidade, tomam o mercado por referência e ignoram a demanda da maior parte da sociedade, bem como ignoram a cidade ilegal.

O compromisso pré-eleitoral com um programa de governo da coalização é pouco praticado. As disputas provocadas pela discussão do PD acabam explicitando opiniões divergentes e interesses conflituosos entre as diferentes secretarias e áreas do governo.

Nos casos estudados, a apresentação e a discussão dos estudos e das pesquisas com o diagnóstico e a transparência do processo - por meio da divulgação do calendário das atividades aos delegados, às entidades e no site - foram fundamentais para que esses conflitos aflorassem e para que as propostas de conciliação fossem construídas. Os conteúdos não acordados foram encaminhados para votação no Congresso da Cidade (Figura 1).

\footnotetext{
${ }^{7}$ Segundo inciso I do art. 20 do Estatuto da Cidade: "I - garantia do direito a cidades sustentáveis, entendido como o direito à terra urbana, à moradia, ao saneamento ambiental, à infraestrutura urbana, ao transporte e aos serviços públicos, ao trabalho e ao lazer, para as presentes e futuras gerações" (Brasil, 2001).
}

\section{Na leitura da cidade, a construção das pautas}

\section{Pesquisas: a forma de coleta dos resultados}

Para a elaboração do PD, é necessário ouvir moradores das diferentes regiões da cidade e segmentos organizados da sociedade. A diversidade das visões sobre a cidade construída pelos segmentos organizados deve ser explicitada, trazendo para a esfera pública os interesses que embasam as visões. O morador vê o conjunto dos bairros a partir do lugar onde vive. 0 desafio é sensibilizar a população para o assunto e também trazer a opinião do maior número de moradores sobre os desejos e as expectativas com relação à cidade, rompendo com a invisibilidade dos processos urbanos que acontecem nas periferias e revelando a diversidade e a desigualdade entre as "cidades" que compõem uma mesma cidade (Harvey, 2011). As pautas assim levantadas orientam a definição das propostas.

Nos processos desenvolvidos em Vinhedo e Jundiaí, foram realizadas três pesquisas para a elaboração da leitura comunitária, trazendo a percepção do público em geral e dos segmentos organizados. A primeira foi realizada com um formulário curto, que incluiu uma breve explicação sobre o PD, distribuído com as contas de água, entregue em toda a cidade, para as economias residenciais e comerciais de devolução voluntária. 0 objetivo dessa pesquisa foi essencialmente sensibilizar a população para a participação no processo de elaboração do PD, informar que o processo de revisão da legislação estava em andamento e introduzir o tema na cidade. As perguntas procuravam levantar a identificação de traços da imagem da cidade percebidos pela população, as expectativas quanto ao futuro da cidade e o grau de satisfação com recursos municipais e serviços públicos disponíveis. A Figura 2 é um exemplo do instrumento utilizado em Vinhedo. À esquerda, uma breve explicação sobre o que é o PD; à direita, um formulário de rápido e fácil preenchimento e com perguntas abertas.

A primeira pesquisa teve devolução voluntária, nos meses de dezembro/2005 e janeiro/2006 em Vinhedo e março/maio de 2014 em Jundiaí. Permitiu levar a consulta a toda a cidade. Estatisticamente, a pesquisa resultou em amostra válida, inclusive por bairros (Quadro 4). Proporcionou à equipe captar percepções distintas sobre a cidade em geral e em 


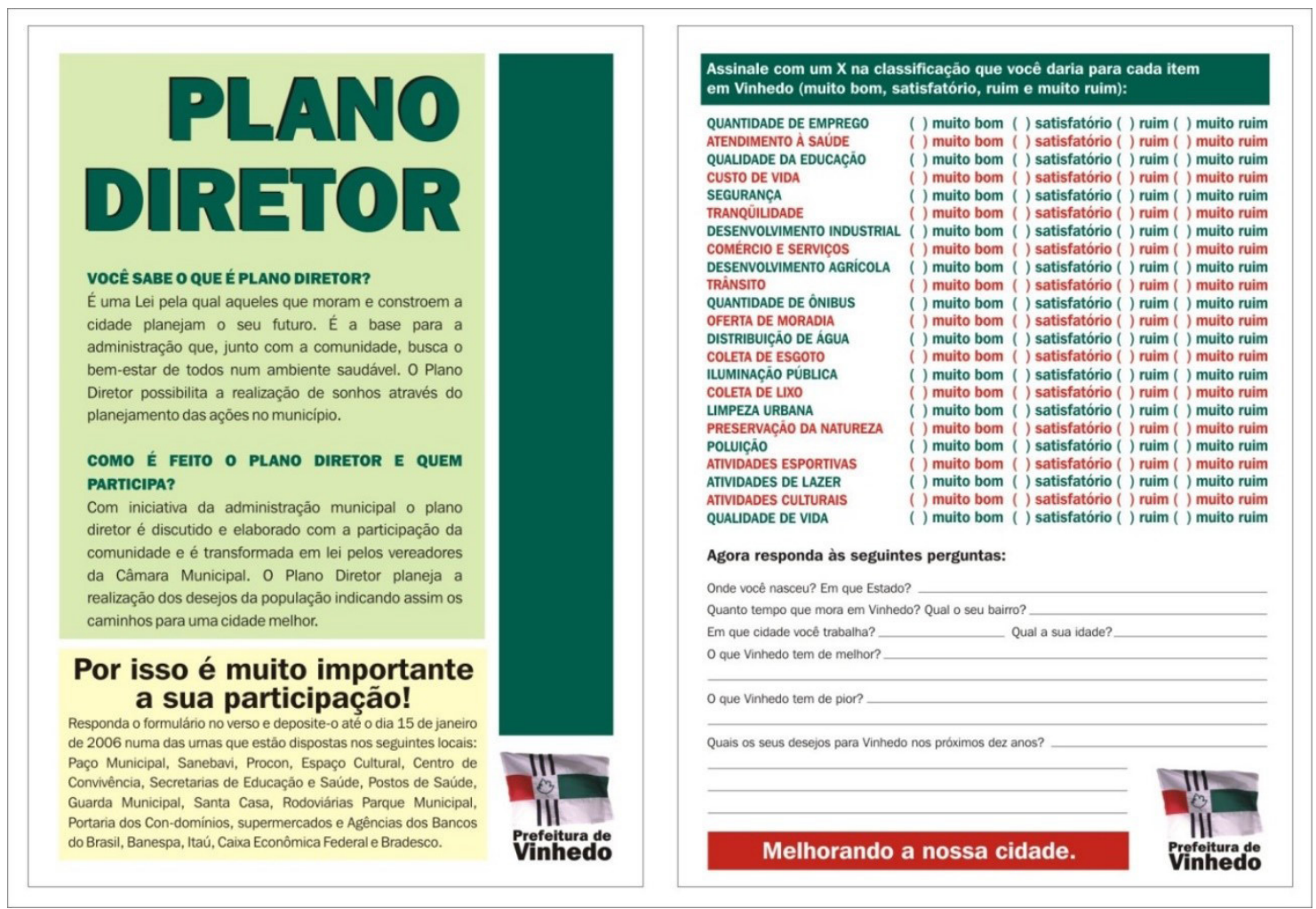

Figura 2 - Formulário de pesquisa veiculado na conta d'água ${ }^{8}$ Fonte: Prefeitura Municipal de Vinhedo (2006).

Quadro 4 - Principais informações sobre a pesquisa inicial

\begin{tabular}{|l|l|l|}
\hline & \multicolumn{1}{|c|}{ Vinhedo } & \multicolumn{1}{c|}{ Jundiaí } \\
\hline Veículo de distribuição & Conta d'água para 15.640 endereços por meio da SANEBAVl9. & Conta d'água para cerca de 150 mil endereços por meio da DAE ${ }^{10}$. \\
\hline Meio de coleta & 60 urnas no Paço Municipal, agências bancárias, condomínios. & 39 urnas em supermercados, lotéricas e agências bancárias. \\
\hline Amostra tabulada & 594 (3,8\% dos questionários). & 2.077 (1,38\% dos domićlios), representando 59 bairros dos 73 existentes. \\
\hline
\end{tabular}

Fonte: Elaboração própria.

relação a cada bairro, no que se refere à imagem e à avaliação dos serviços urbanos.

A Figura 3 exemplifica a importância da espacialização por bairros e apresenta diferentes resultados. À direita, estão as respostas sobre o nível de satisfação quanto à oferta de moradia, que varia conforme o bairro; à esquerda, vemos os resultados sobre custo de vida, homogêneos em toda a cidade.

\footnotetext{
${ }^{8}$ A Figura 2 reproduz o formulário utilizado em Vinhedo.

${ }^{9}$ Saneamento Básico Vinhedo: autarquia municipal.

${ }^{10}$ DAE S.A. - Água e Esgoto: sociedade de economia mista que atua no saneamento de Jundiaí.
}

O segundo formulário aprofundou a investigação. Abordou novamente o tema da identidade da cidade e apontou o grau de satisfação sobre a qualidade dos serviços urbanos. Levantou o desejo da população em relação ao desenvolvimento econômico e incluiu a escuta quanto à expectativa do planejamento urbano para o equacionamento de problemas. Aprofundou o levantamento de problemas, destacando os três principais. Nesse caso, o questionário mais extenso foi distribuído nas escolas de ensino médio e fundamental da rede pública, tendo como público-alvo os pais de alunos. Os professores, informados anteriormente, distribuíram os questionários em sala, esclarecendo dúvidas. Os alunos levaram para casa o questionário 


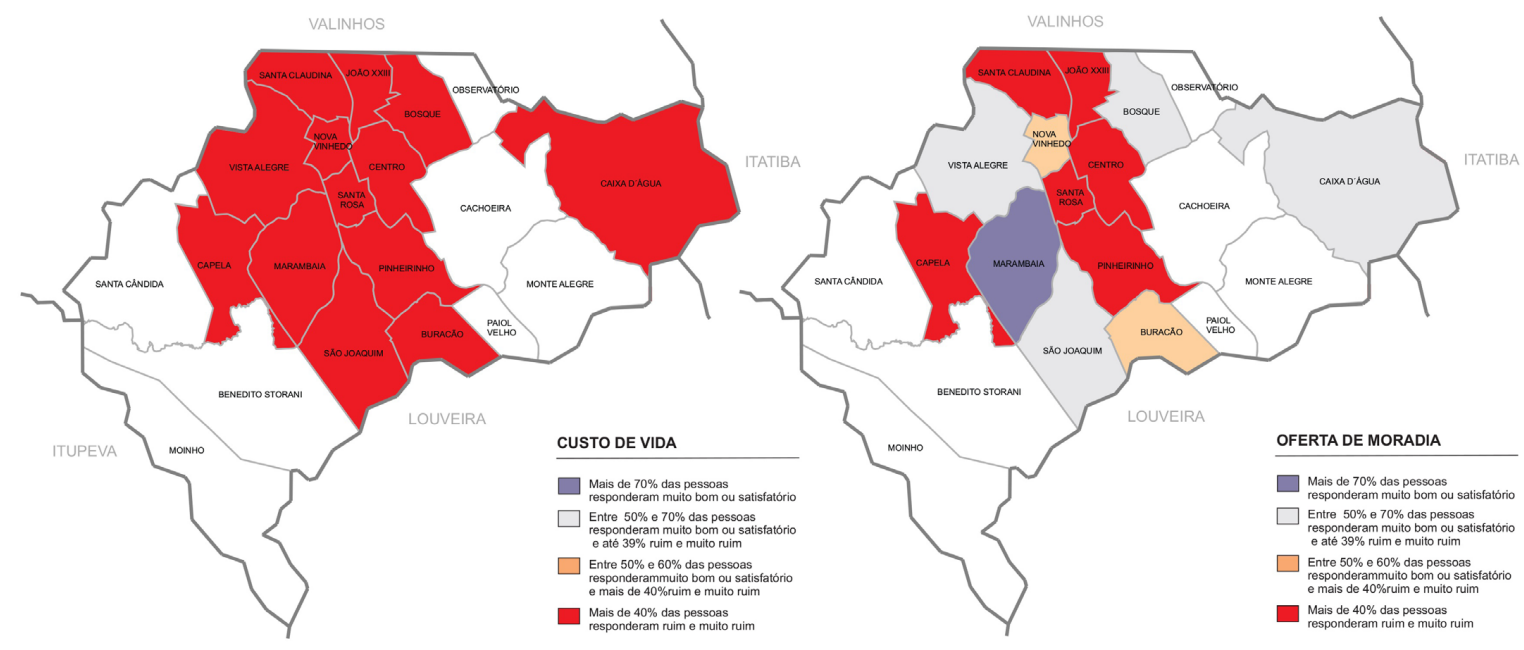

Figura 3 - Sistematização da pesquisa espacializada (Vinhedo)

Fonte: Demacamp (2006).

Quadro 5 - Principais informações sobre a segunda pesquisa, ocorrida nas escolas ${ }^{11}$

\begin{tabular}{|c|c|c|}
\hline & Vinhedo & Jundiaí \\
\hline Objetivos & \multicolumn{2}{|c|}{$\begin{array}{l}\text { - Identificar a imagem da cidade. } \\
\text { - Expectativas quanto ao futuro da cidade. } \\
\text { - Grau de satisfacãóo com recursos disponíveis. } \\
\text { - } 0 \text { olhar dos bairros por tema. } \\
\text { - Principais problemas. } \\
\text { - Accões/atividades consideradas prioritárias }\end{array}$} \\
\hline Distribuiç̄õo & $\begin{array}{l}7.995 \text { questionários. } \\
\text { - } 6 \text { mil nas escolas de ensino fundamental e EJA (Educacãão } \\
\text { de Jovens e Adultos). } \\
\text { - } 450 \text { idosos. } \\
\text { - } 80 \text { jovens de programas sociais. } \\
\text { - } 13 \text { entidades que compōem } 0 \text { Grupo Gestor. }\end{array}$ & $\begin{array}{l}28.831 \text { questionários. } \\
15.998 \text { nas escolas de ensino fundamental e } 12.833 \text { nos } 2^{\circ} \text { e } 3^{\circ} \\
\text { anos do ensino médio das escolas estaduais. }\end{array}$ \\
\hline $\begin{array}{l}\text { Forma de apresentaç̃õo, preenchimento e } \\
\text { coleta }\end{array}$ & $\begin{array}{l}\text { - Professor acompanhado de cartitha do PD. } \\
\text { - Monitor acompanhado de cartilha do PD. }\end{array}$ & $\begin{array}{l}\text { Professores apresentam os questionários aos alunos, que devem } \\
\text { preenchê-los como dever de casa com a família. }\end{array}$ \\
\hline Devoluc̦ão & $\begin{array}{l}2.751 \text { questionários. } \\
\text { - Para professor em sala de aula. } \\
\text { - Para monitor no mesmo dia da oficina. } \\
\text { - Por e-mail para Prefeitura. }\end{array}$ & $\begin{array}{l}\mathbf{5 . 6 7 2} \text { questionários } \\
\text { (19,6\% dos } 28.831 \text { distribuídos). }\end{array}$ \\
\hline Amostra tabulada & 1.535 questionários. & Todos os devolvidos. \\
\hline
\end{tabular}

Fonte: Elaboracãa própria.

para responder com o grupo familiar. $\mathrm{O}$ instrumento foi eficaz no processo de formação da cidadania e teve maior número de devoluções (Quadro 5).

A amostra por bairro foi dimensionada para representatividade da população do bairro em relação ao total do município. No caso de Jundiaí, dos 73 bairros, 59 , que representam $98 \%$ da população, obtiveram amostra válida. Os bairros que não atingiram bases

\footnotetext{
${ }^{11}$ Em Vinhedo, a Secretaria de Educação definiu como tema do ano letivo de 2006: "A Vinhedo que queremos".
}

suficientes para análise foram agrupados aos seus vizinhos ou incluídos na análise dos totais do município. Em Vinhedo, alcançou-se a amostra em todos os bairros.

\section{A pesquisa com as entidades}

As duas pesquisas anteriores trouxeram ao processo de formulação do PD informações sobre a percepção da população moradora sobre sua cidade, mas outra 
dimensão de conhecimento era também necessária: as percepções dos segmentos sociais organizados.

Estes se organizam em função de interesses comuns e pautas específicas, disputam o território da cidade de forma distinta, compõem conselhos municipais, elegem vereadores. 0 primeiro passo é identificá-los no contexto municipal. Quem são os segmentos que disputam a cidade? Empresários ligados à produção da cidade, como construtoras, imobiliárias, financeiras, ONGs militantes de direitos sociais, políticas setoriais, meio ambiente, arte e cultura, entidades técnicas, acadêmicas e de pesquisa, sindicatos e associações de moradores são grupos que devem ser identificados e abordados.

0 instrumental utilizado nos casos estudados é apresentado no Quadro 6.

Com resultados de consultas públicas abrangentes, que expressem a opinião das diferentes regiões da cidade, o diagnóstico técnico atinge outro nível de legitimidade.

A leitura comunitária efetivada por meio da aplicação de pesquisas qualifica o dado técnico. Como um exemplo, em Vinhedo, detectou-se a existência de déficit habitacional a partir dos dados do censo do IBGE. A Prefeitura afirmava não ser um problema na cidade, mas $47 \%$ das respostas sobre o principal problema da cidade foram a falta de moradias (Figura 4).

Outro exemplo foi o contraste entre a imagem de qualidade ambiental de Vinhedo e seus condomínios, como principal tema da cidade, e os desejos da população para o desenvolvimento econômico da cidade com base na indústria (53\%), o que já causa diversos impactos ambientais negativos, em especial na rede hidrográfica. Essas informações foram decisivas para o surgimento de propostas de negociação de ações de compensação ambiental, que trouxeram benefícios para os moradores da cidade.

A opinião da população sobre a cidade revelada nas pesquisas evidencia as contradições existentes e expõe posições divergentes entre segmentos, movimentos sociais e governantes. Quando 29\% das respostas sobre o que Jundiaí tem de melhor se concentraram

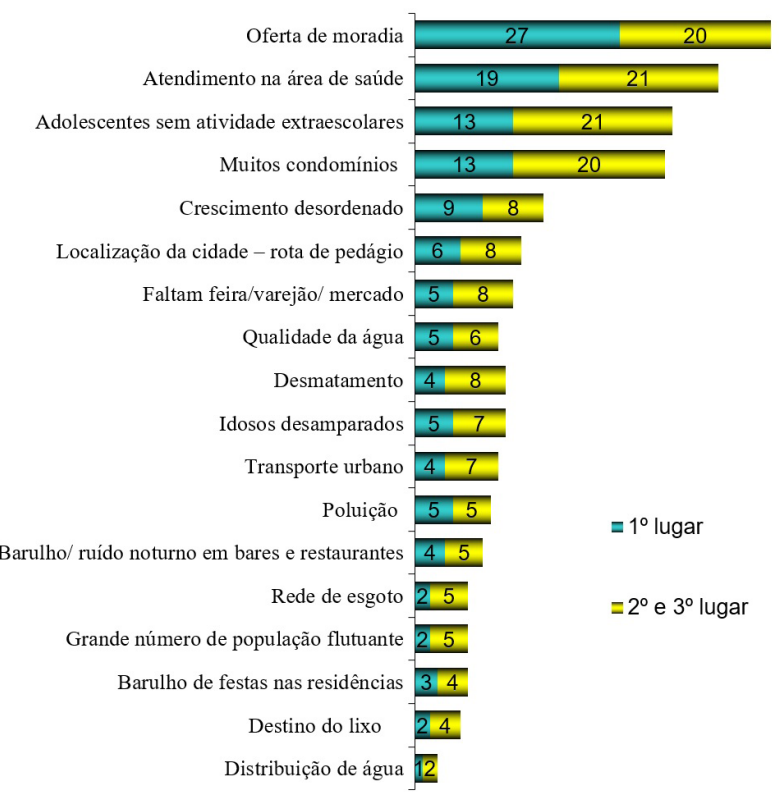

Figura 4 - Principais problemas de Vinhedo detectados pela pesquisa Fonte: Demacamp (2006).

Quadro 6 - Principais informações sobre a pesquisa direcionada aos segmentos sociais organizados

\begin{tabular}{|c|c|c|}
\hline & Vinhedo & Jundiaí \\
\hline Distribuiç̃óo e devolução & \multicolumn{2}{|l|}{ E-mail. } \\
\hline Público-alvo & $\begin{array}{l}24 \text { entidades dos segmentos: } \\
\text { - ONGs. } \\
\text { - Entidades técnicas, acadêmicas e de pesquisa. } \\
\text { - Empresários ligados à produção da cidade (vitivinicultores, indústria, setor } \\
\text { imobilíario). } \\
\text { - Movimentos sociais. }\end{array}$ & $\begin{array}{l}70 \text { entidades dos segmentos: } \\
\text { - ONGS. } \\
\text { - Entidades técnicas, acadêmicas e de pesquisa. } \\
\text { - Empreśrios ligados à produção da cidade (CIESP/SESI, setor } \\
\text { imobilíário). } \\
\text { - Movimentos sociais. }\end{array}$ \\
\hline Respostas & 15 & $\begin{array}{l}23 \\
\text { - ONGs (7). } \\
\text { - Entidades técnicas, acadêmicas e de pesquisa (7). } \\
\text { - Empresários (3). } \\
\text { - Movimentos sociais (6). }\end{array}$ \\
\hline
\end{tabular}

Fonte: Elaboração própria. 

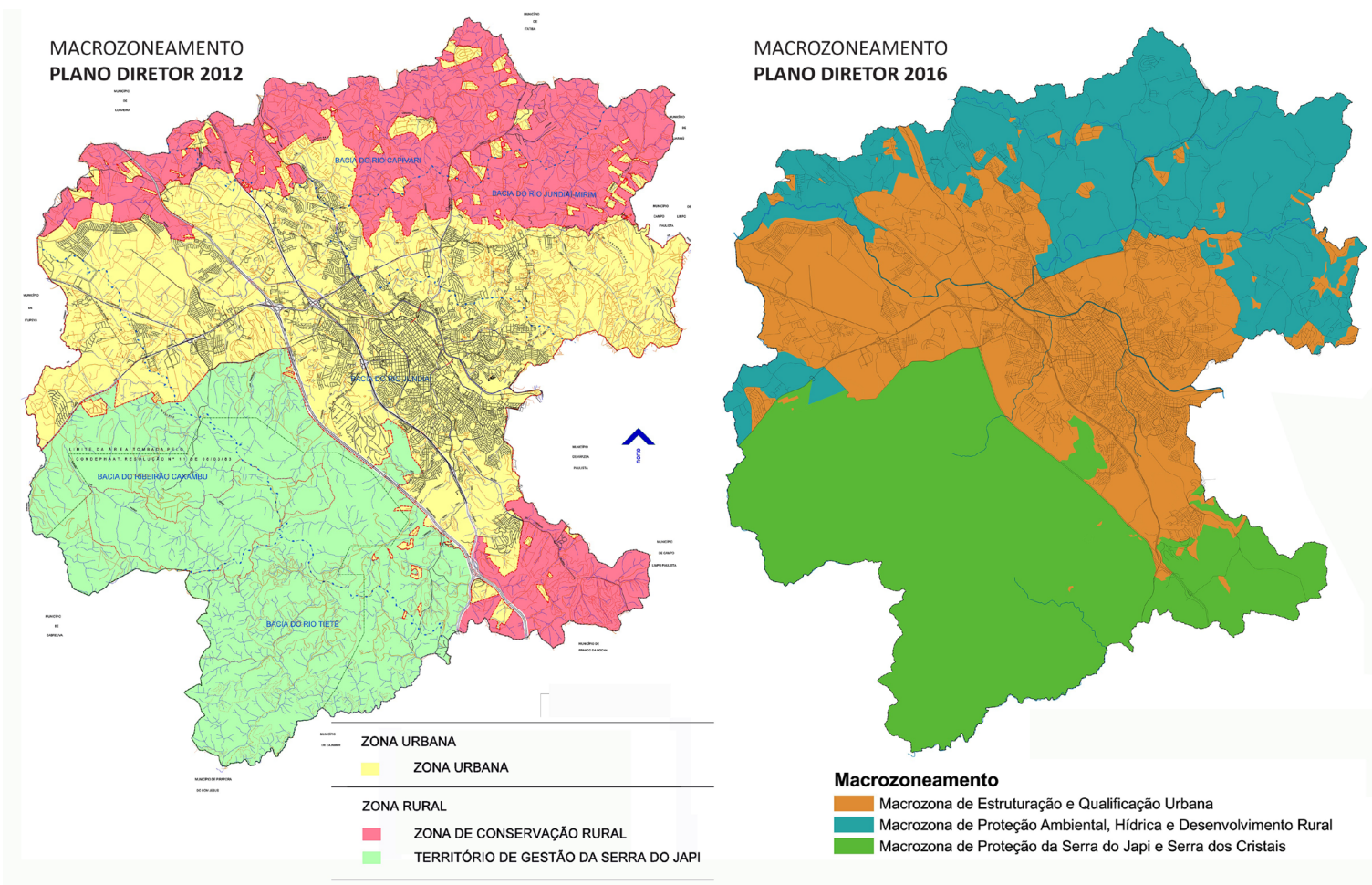

Figura 5 - Limite do perímetro urbano em Jundiaí, antes e depois da revisão do Plano Diretor 2012 e 2016

Fonte: Elaboração própria (2016).

na Serra do Japi, natureza, clima e água, explicitou-se a prioridade à proteção da bacia produtora de água como uma diretriz norteadora da concepção do projeto de cidade. Essa revelação mostrou um conflito em função da existência de inúmeros loteamentos irregulares em processo de regularização na Bacia do Jundiaí-Mirim. Foi possível a reversão de uma área com características rurais que estava zoneada para o uso industrial. A proposta do PD resultou no aumento da zona rural com a ampliação de áreas destinadas à produção agrícola (Figura 5).

Em Jundiaí, no mapa de 2012, a macrozona urbana equivale ao perímetro urbano. No mapa de 2016, destacam-se os trechos oeste, sul e nordeste, nos quais houve a reversão dessas áreas, mantendo o uso rural graças à pressão dos produtores rurais que, na segunda audiência pública realizada pela Câmara, ocuparam as imediações do prédio com 70 tratores ${ }^{12}$.

Em Vinhedo, no mapa de 1984, não havia zona rural (Figura 6). Na lei de 2007, destacam-se os trechos oeste, sul e nordeste, nos quais houve a reversão do perímetro urbano, reconhecendo-se o uso rural,

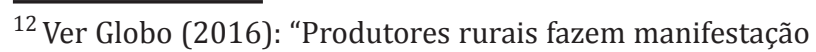
com tratores em Jundiaí".
}

contrariando a tendência dos PDs submetidos a pressões do setor imobiliário, que vê na ampliação da área urbana grande lucratividade.

Em Jundiaí, a percepção do problema habitacional, com $49 \%$ das respostas para "os lançamentos não atendem a maioria da população" (Figura 7), trouxe para o debate que não faltam terras para habitação nem incentivos aos incorporadores, mas era necessário induzir a produção de unidades habitacionais mais baratas, que pudessem atender às diferentes faixas de renda.

As pesquisas desmistificam os discursos dos setores dominantes, dando visibilidade a outras opiniões e revelando que um número significativo de munícipes tem outras pautas de discussão sobre a cidade, diferentes das do setor imobiliário.

\section{Propostas e mesas de negociação: processo de construção de uma lei territorial}

Apresentado o diagnóstico, elaborada a proposta de governo e coletadas e produzidas as contrapropostas dos segmentos, o próximo passo é a busca de consensos. A publicidade da proposta se dá em um fórum aberto, 

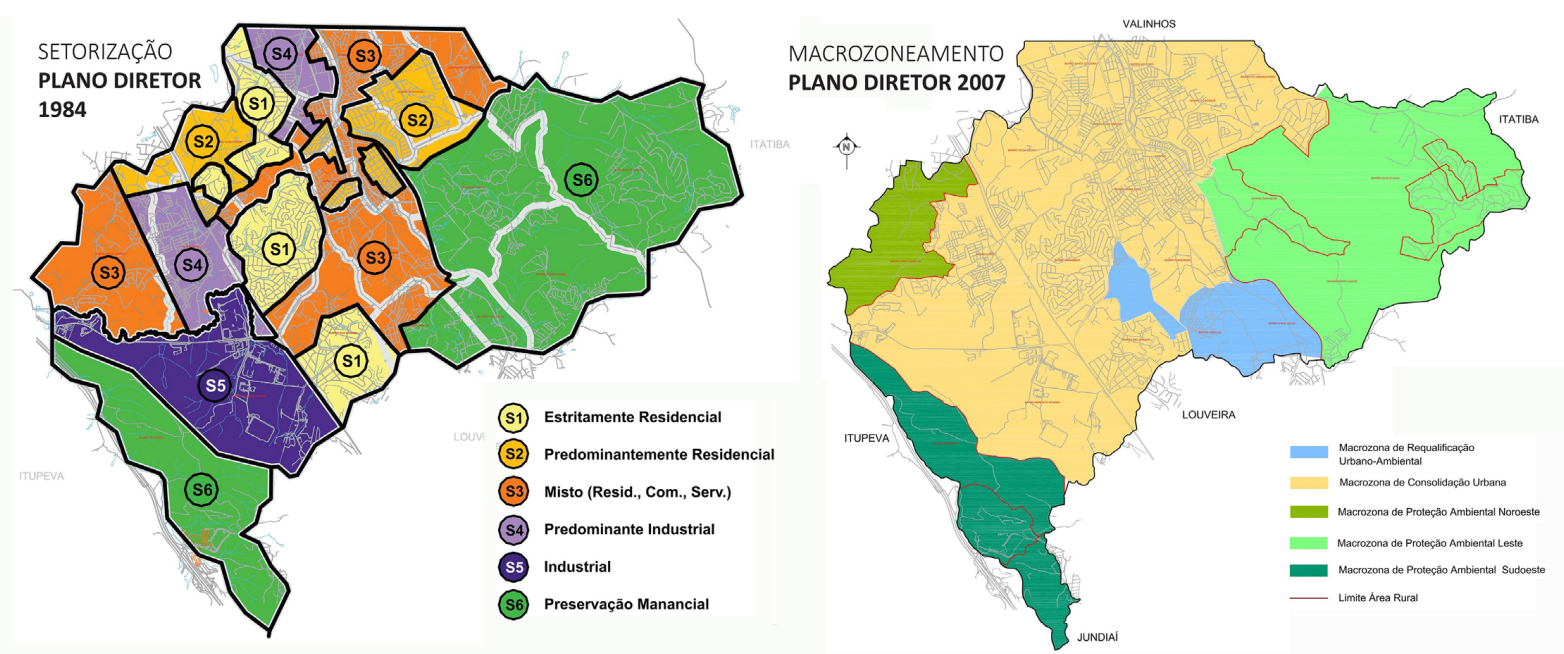

Figura 6 - Limite do perímetro urbano em Vinhedo, antes e depois da revisão do Plano Diretor 1984 e 2007 Fonte: Demacamp (2006).
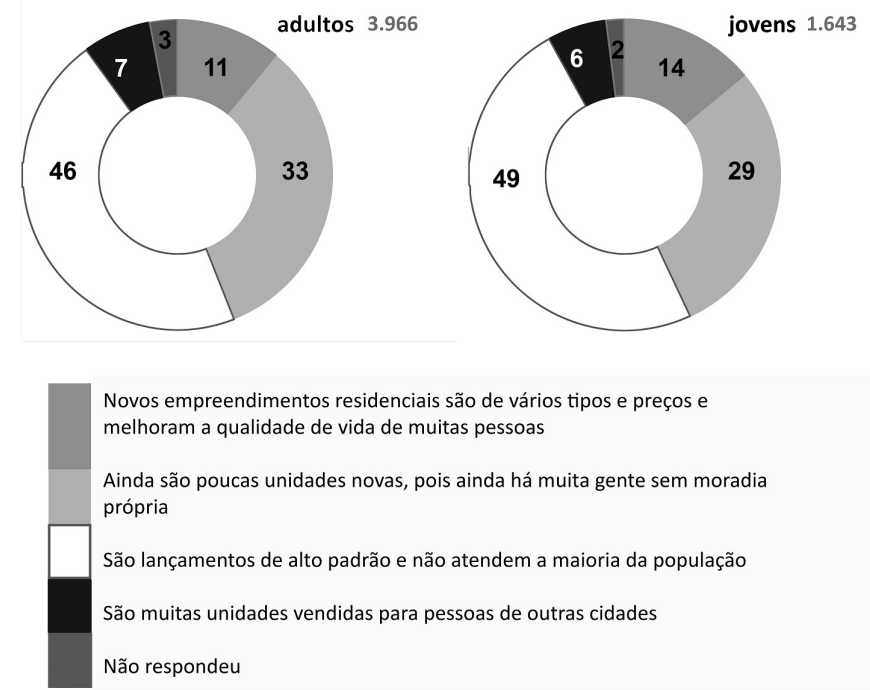

Figura 7 - Resultado em Jundiai da pergunta: Assinale o que mais você pensa sobre a questão de moradia.... Fonte: Demacamp (2015a, 2015b).

do qual qualquer cidadão pode participar, mas as decisões devem ocorrer no âmbito dos delegados, eleitos e capacitados para discutir representando seus pares.

Na experiência de Jundiaí (2016b), qualquer cidadão poderia propor alterações ou sugestões pelo website da Prefeitura. Foram recebidas 863 propostas sistematizadas por tema, analisadas e respondidas se acolhidas ou rejeitadas. Foram evidenciados 198 conflitos, discutidos no fórum de delegados. Se não resolvidos, eram submetidos à votação na plenária do Congresso da Cidade, realizado no final do processo de elaboração do projeto de lei pelo Executivo, antes do envio à Câmara de Vereadores.

0 processo de sistematização e de discussão até a votação das propostas no Congresso da Cidade levou cinco meses no caso de Vinhedo e 12 meses em Jundiaí (Quadro 7).

Mesmo assim, em Jundiaí, os vereadores propuseram 72 emendas ao texto de lei. 0 Executivo as classificou quanto ao impacto técnico que causariam ao projeto original em três categorias: impacto (sem, pequeno e grande), modificação pontual e contrária ao processo participativo. Trinta e seis dessas emendas contrariavam 
deliberações do projeto original. Dessa forma, foi possível que os delegados compreendessem as negociações em pauta, mobilizando-se para interferir e pressionar a Câmara. Esse processo garantiu que nenhuma modificação de grande impacto fosse aprovada.

Foi proposta a inclusão de uma nova área como ZEIS para atendimento à população moradora em uma favela próxima.

Importante dizer que o amplo processo de discussão aberto, com a participação dos diferentes segmentos, não impediu a atuação nos setores econômicos com a prática de lobby. Em Jundiaí, o grupo denominado FORCIS - Fórum Regional de Comércio, Indústrias e Serviços de Jundiaí - , composto por representantes do setor imobiliário e arquitetos ligados ao Instituto dos Arquitetos do Brasil (IAB), contratou um estudo contestando o PD proposto. Entretanto, os vereadores julgaram as críticas improcedentes, reconhecendo a legitimidade do projeto de lei encaminhado pelo Executivo. Em Vinhedo, os representantes dos loteamentos fechados apelaram ao Judiciário para paralisar o processo de votação da lei na Conferência do Plano, com a expedição de duas liminares, que atrasaram os processos de envio do projeto à Câmara. Mas isso não prejudicou a integridade da lei aprovada pelos vereadores.

\section{Discussão: avanços no conhecimento e na prática profissional entre contradições}

No processo de discussão participativa de um PD, muitos atores são envolvidos, incluindo nesse universo: sociedade civil organizada, movimentos sociais e Executivo. No âmbito dos delegados, são claras as divergências de ideias e de interesses, que, durante o processo, diluem-se e ganham força por meio da aproximação entre segmentos distintos e consensos que vão se construindo durante a discussão.

Na esfera do governo, duas frentes se apresentam na correlação de forças políticas entre governantes e partidos. Governos de coalizão que reúnem legendas partidárias de posições extremadas necessariamente entram em rota de colisão nesses processos, divergindo sobre aspectos técnicos da proposta do PD.

A ideologia do patrimonialismo reflete-se no serviço público, no comportamento dos técnicos e nos procedimentos administrativos que ainda trazem a antiga compreensão da propriedade privada no Brasil, aceitando como natural a soberania do direito do proprietário sobre a função social da cidade e da propriedade, conforme explica Fernandes (2013, p. 223):

Esse processo de mercantilização das cidades tem demandado o reforço da cultura jurídica

Quadro 7 - Algumas informações sobre o processo de negociação e construção da lei

\begin{tabular}{|c|c|c|c|c|}
\hline & $\begin{array}{l}\text { Período de discussão e } \\
\text { recepção de propostas }\end{array}$ & Reuniões de negociação & Emendas votadas na Câmara & $\begin{array}{c}\text { Diferenças entre o PL e a lei } \\
\text { aprovada }\end{array}$ \\
\hline Jundiaí & $\begin{array}{l}500 \\
\left(1^{0} \text { fase: de marcso/2015 a }\right. \\
\text { julho/2015). } \\
363 \\
\text { (2 }{ }^{0} \text { fase - PL: de dezembro/2015 a } \\
\text { fevereiro/2016). }\end{array}$ & $\begin{array}{l}160 \text { reuniões de negociação. } \\
\text { - } 75 \text { soluções consensuadas em } \\
\text { plenária. } \\
\text { - } 28 \text { contrapropostas de governo } \\
\text { aprovadas. } \\
\text { - } 33 \text { propostas retiradas. } \\
\text { - } 23 \text { soluções definidas nos debates. } \\
\text { - } 16 \text { pontos restantes de conflitos } \\
\text { para votação no Congresso. }\end{array}$ & $\begin{array}{l}\text { - } 11 \text { emendas } \\
\text { (1 delas com } 45 \text { alterações). } \\
\text { - } 4 \text { subemendas. }\end{array}$ & $\begin{array}{l}\text { - Detalhamento da Zona Especial } \\
\text { Proteccão Ambiental. } \\
\text { - Inclusão de exigência de certidão do } \\
\text { DAE para empreendimentos habitacionais } \\
\text { multifamiliares. } \\
\text { - Aumento de gabarito em três corredores } \\
\text { urbanos. }\end{array}$ \\
\hline Vinhedo & $\begin{array}{l}60 \\
\text { (de agosto a dezembro de 2006). }\end{array}$ & 22 reuniões de negociação. & $\begin{array}{l}\text { - } 15 \text { emendas modificativas. } \\
\text { - } 3 \text { aditivas e } 1 \text { retirada. }\end{array}$ & $\begin{array}{l}\text { - Alteração em prazos: de } 18 \text { para } 3 \\
\text { meses, para elaboração de planos seto- } \\
\text { riais; de } 30 \text { para } 90 \text { dias, para emissão } \\
\text { de diretrizes; de } 6 \text { para } 12 \text { meses, para } \\
\text { declaração dos proprietários em Zona } \\
\text { Especial de Interesse Agrícola. } \\
\text { - Inclusão da acessibilidade universal } \\
\text { como requisito para a elaboracãa do } \\
\text { Projeto de Reabilitação do Centro. }\end{array}$ \\
\hline
\end{tabular}

Fonte: Elaboração própria. 
individualista e patrimonialista tradicional, vigente e dominante pré-Estatuto da Cidade, com a propriedade imobiliária concebida quase que exclusivamente como mercadoria, seu valor de troca prevalecendo sobre qualquer valor de uso, e a possibilidade de usar/gozar/dispor do bem imóvel sendo também interpretada como a possibilidade livre de não usar/gozar/dispor do bem - em outras palavras, de especular.

Apoios e alianças construídas em função do voto, internalizadas dentro e fora do Executivo, polarizam decisões incluídas no PD, mudando rumos das propostas.

0 papel de decisão do prefeito é central, no sentido de mediar o diálogo intersecretarial, decidindo quando há divergências entre as pastas e administrando conflitos entre secretarias. Também dá o aval ao processo sobre questões trazidas pelos setores econômicos e sociedade, relativas ao uso e à ocupação do solo, remetendo-as à esfera pública de discussão. A participação permite compartilhar articulações de enfrentamento político relativos aos conteúdos do PD com a sociedade. Esse procedimento fortalece o processo e resguarda a figura do chefe do Executivo.

O Judiciário também exerce papel de extrema importância, na medida em que, acompanhando o processo, pode ser chamado para garantir sua continuidade. Em Vinhedo, o Ministério Público (MP) teve papel fundamental no apoio ao governo no enfrentamento da situação dos loteamentos fechados. Em Jundiaí, a revisão antecipada do PD anterior, que havia sido aprovado em 2012, foi respaldada pelo MP.

Processos dessa magnitude exigem equipes qualificadas, dedicadas exclusivamente à condução do PD. É necessário investimento em construir um processo de elaboração dos documentos técnicos contando com equipes multidisciplinares, mas também processos de discussão pública que envolvam profissionais especializados para essa tarefa e que conheçam os conteúdos relacionados ao planejamento urbano. Assim, o edital para contratação deve incluir a definição de uma equipe mínima especializada nos temas do planejamento e gestão urbana, do direito urbanístico e da participação social, levando em conta o valor da sua remuneração conforme a necessária experiência. $\mathrm{O}$ dimensionamento de horas e custos do trabalho é diretamente proporcional ao nível de qualificação dos profissionais solicitados e também ao grau de aprofundamento ao qual se pretende chegar, tanto internamente ao governo quanto no processo participativo. Para construir o consenso sobre a proposta de governo, antes do envio à Câmara Municipal, foram realizadas, em Vinhedo, 22 reuniões públicas de negociação, e em Jundiaí, 160, discutindo-se ponto a ponto a minuta, o que demandou um acréscimo de horas de trabalho da equipe para mediar as tratativas.

Como o tempo de acompanhamento de reuniões não é predeterminado, é aconselhável que os contratos possibilitem o acréscimo de atividades com remuneração adequada, semelhante ao que ocorre na execução de obras com a utilização de atas de registros de preços, na qual se fixaria o preço unitário de um serviço, abrindo a possibilidade de solicitação de serviços sob demanda.

No Brasil, ainda prevalece a cultura de pouca importância às atividades de planejamento, gerando estruturas e equipes fracas e restrição de recursos para contratação de consultorias. A experiência da consultoria para processos, e não somente para produtos, tem resultado na melhoria dos quadros técnicos das Prefeituras, sem que esse resultado seja formalmente reconhecido pelos gestores, muitas vezes inexperientes ou pouco afeitos ao planejamento territorial.

\section{Conclusões}

A análise das experiências aqui trazidas mostra a importância dos processos participativos para garantir o resultado final das leis e sua aplicabilidade. Foi possível avançar na qualidade do pacto territorial em temas polêmicos, como o perímetro urbano, os loteamentos fechados, a regulamentação dos instrumentos urbanísticos, a demarcação de ZEIS, a instituição de conselhos deliberativos de política urbana e a constituição de fundos por meio da instituição de um processo transparente de exposição de contradições. Após estudar mais de 100 PDs, Santoro (2012) avalia que "Vinhedo é mais criativo" na sua proposição no caso de loteamentos fechados, incluindo a exigência de compensação de áreas públicas fechadas. Rolnik (2008, p. 107) considera que o PD de Vinhedo, "[...] trazendo uma metodologia aliada à decisão da autoaplicabilidade do plano [...] fez do processo uma verdadeiramente pública", sendo na RMC

[...] a que mais construiu um processo de discussão e negociação pública do plano, e apesar dos conflitos logrou construir um consenso, 
respeitando a participação da sociedade civil em todas as etapas de elaboração do plano (Rolnik, 2008, p. 93).

Contradições são inerentes às disputas, em se tratando de grupos que lutam pelo território. As pesquisas abrem a possibilidade de inserir novos atores, além de trazer um retrato da cidade observado sob diferentes pontos de vista. Permitem considerar outros condicionantes para a definição de um novo ordenamento territorial menos propenso ao setor imobiliário: a imagem, a identidade da cidade, a qualidade de vida de todos os moradores e o desejo sobre seu destino.

0 rigor do método permite confiabilidade nas conclusões aferidas. Amostras estatísticas, ferramentas digitais, cronogramas apresentados e periodicidade nos encontros presenciais dão transparência e credibilidade ao processo.

0 voto final de cada artigo no âmbito da arena pública, explicitando divergências e conflitos, retira do Executivo a exclusividade do resultado, colocando a população, por meio dos colegiados, à frente para defesa do projeto. Técnicos e gestores são integrantes desse grupo, mas não mais assumem sozinhos a responsabilidade por sua aprovação. Possuem apoio de um grupo maior, mais eclético, menos associado ao prefeito e suas alianças políticas, mais autônomos e mais comprometidos com o próprio município.

\section{Agradecimentos}

Agradecemos ao CNPq e à PUC-Campinas pelo apoio recebido, que viabilizaram o estágio de pós-doc da primeira autora $(2015 / 16)$, à equipe da Demacamp e às Prefeituras de Jundiaí e de Vinhedo.

\section{Referências}

Alves-Mazzotti, A. J. (2006). Usos e abusos dos estudos de caso. Cadernos de Pesquisa, 36(129), 637-651. http:// dx.doi.org/10.1590/S0100-15742006000300007.

Brasil. (2001, 11 de julho). Lei Federal no 10.257, de 10 de julho de 2001. Estatuto da Cidade. Regulamenta os arts. 182 e 183 da Constituição Federal, estabelece diretrizes gerais da política urbana e dá outras providências. Brasília: Diário Oficial da União.
Brasil. Conselho Federal de Engenharia, Arquitetura e Agronomia - CONFEA. (2004). Plano diretor participativo: guia para elaboração pelos municípios e cidadãos. Brasília: Ministério das Cidades.

Bueno, L. M. M., \& Cymbalista, R. (2007). Planos Diretores Municipais: novos conceitos de planejamento territorial. São Paulo: Annablume.

Burnett, F. L. (2011). Da tragédia urbana à farsa do urbanismo reformista: a fetichização dos Planos Diretores Participativos. São Paulo: FANEMA/Annablume.

Consórcio Demacamp/Polis/Oficina. (2013). Plano de Trabalho - Estudos urbanísticos e a elaboração, com participação social, dos instrumentos de política urbana, essenciais e estratégicos relacionados ao desenvolvimento socioeconômico da macroárea de influência da Ponte Salvador - Itaparica/SVO. Campinas.

Cymbalista, R., \& Santoro, P. (Eds.). (2009). Planos Diretores: processos e aprendizados. São Paulo: Instituto Pólis.

Demacamp. (2006). Plano Diretor Participativo de Vinhedo. Relatório de Leitura. Campinas.

Demacamp. (2015a). Leitura comunitária: plano diretor participativo do município de Jundiaí. Relatório de Leitura. Campinas. Recuperado em 25 de maio de 2017, de http:// planodiretor.jundiai.sp.gov.br/wp-content/uploads/2015/02/ Leitura-Comunit\%C3\%A1ria-JUNDIA\%C3\%8D.pdf

Demacamp. (2015b). Plano Diretor Participativo de Jundiaí - SP. Relatório de Leitura. Campinas. Recuperado em 25 de maio de 2017, de http://planodiretor.jundiai.sp.gov.br/ wp-content/uploads/2015/06/Leitura-t\%C3\%A9cnica_ PDJundia\%C3\%AD_FINAL_rev04-08_menor.compressed.pdf Faoro, R. (1977). Os donos do poder. Porto Alegre: Globo. Fernandes, E. (2013). Estatuto da Cidade, mais de 10 anos depois. Revista UFMG, 20(1), 212-233.

Ferreira, J. (2009). 0 processo de urbanização brasileiro e a função social da propriedade urbana. In Brasil. Ministério das Cidades. Ações integradas de urbanização de assentamentos precários. Brasília: Ministério das Cidades, Aliança de Cidades.

Freitas, E. (2008). Loteamentos fechados (Tese de doutorado). Faculdade de Arquitetura e Urbanismo, Universidade de São Paulo, São Paulo. 
Fundação SEADE. (2004). Perfil dos Municípios Paulistas: dados básicos IBGE. São Paulo. Recuperado em 7 de fevereiro de 2018, de http://www.perfil.seade.gov.br/

Globo. (2016, 16 de junho). Produtores rurais fazem manifestação com tratores em Jundiaí. G1, Bom dia Cidade. Recuperado em 25 de maio de 2017, de http://g1.globo. com/sao-paulo/sorocaba-jundiai/bom-dia-cidade/videos/v/ produtores-rurais-fazem-manifestacao-com-tratores-emjundiai/5097587/

Harvey, D. (2011). O enigma do capital e as crises do capitalismo. São Paulo: Boitempo.

Instituto Brasileiro de Geografia e Estatística - IBGE. (2010). Base de informações do Censo Demográfico 2010. Rio de Janeiro.

Jundiaí. (2016a, 7 de julho). Lei no 8.683 de 7 de julho de 2016. Institui o Plano Diretor do município de Jundiaí e dá outras providências. Jundiaí: Prefeitura Municipal. Recuperado em 25 de maio de 2017, de www.jundiai.sp.gov.br

Jundiaí. Prefeitura Municipal - PMJ. (2016b). Plano Diretor Participativo. Jundiaí: Prefeitura Municipal. Recuperado em 25 de maio de 2017, de http://planodiretor.jundiai. sp.gov.br/

Maricato, E. (2006). O Ministério das Cidades e a política nacional de desenvolvimento urbano. Cidades brasileiras: a matriz patrimonialista. Políticas Sociais, 12, 211-220.

Maricato, E. (2011). O impasse da política urbana no Brasil. São Paulo: Vozes.
Oliveira, F. O. (1982). Estado e o urbano no Brasil. Espaço e Debates, 6, 36-54.

Rolnik, R. (2008). Análise crítica dos processos de elaboração de Planos Diretores dos Municípios da região metropolitana de Campinas à luz do Estatuto da Cidade. Campinas: PUC-Campinas. Relatório de Pesquisa.

Santoro, P. (2012). Planejar a expansão urbana: dilemas e perspectivas (Tese de doutorado). Faculdade de Arquitetura e Urbanismo, Universidade de São Paulo, São Paulo.

Santos, O., Jr, \& Montandon, D. (Eds.). (2011). Os planos diretores municipais pós-estatuto da cidade: balanço crítico e perspectivas. Rio de Janeiro: Observatório das Cidades, IPPUR/UFRJ.

Villaça, F. (2006). As ilusões do Plano Diretor. São Paulo. Recuperado em junho de 2006, de www.flaviovillaca.arq.br Vinhedo. Prefeitura Municipal - PMV. (2006). Plano Diretor Participativo. Vinhedo: PMV. Recuperado em 25 de maio de 2017, de http://www.vinhedo.sp.gov.br/

Vinhedo. (2007, 17 de janeiro). Lei Complementar $n^{\underline{o}}$ 66, de 17 de janeiro de 2007. Dispõe sobre Plano Diretor Participativo de Vinhedo - PDPV, e dá outras providências. Vinhedo. Recuperado em 25 de maio de 2017, de www. vinhedo.sp.gov.br

Recebido: Jan. 24, 2017

Aprovado: Set. 27, 2017 